\title{
Mineral content, phenolic compounds and bioactive amines of cheese bread enriched with cowpea
}

\author{
Rodrigo Barbosa Monteiro CAVALCANTE ${ }^{1}$ (D), Marcelo Antônio MORGANO ${ }^{2}$, Maria Beatriz Abreu GLÓRIA ${ }^{3}$, \\ Maurisrael de Moura ROCHA ${ }^{4}$, Marcos Antônio da Mota ARAÚJO5, \\ Regilda Saraiva dos Reis MOREIRA-ARAÚJO ${ }^{6 *}$
}

\begin{abstract}
Cheese bread presents great acceptance and market expansion. Due to the lack of standardization in its manufacturing, various ingredients can be added. It was aimed to determine the content of minerals, bioactive compounds and antioxidant activity in cheese bread enriched with biofortified cowpea. Two formulations were prepared, standard cheese bread (without cowpea) and enriched cheese bread. The minerals were analyzed using the plasma emission spectrometry technique with inductive coupling, phenolic compounds and antioxidant activity were determined by spectrophotometry and the amines by High Performance Liquid Chromatography. All analyzes were performed in triplicate and for the comparison of the means between two variables, Student's t-test was applied and for multiple comparisons, the Tukey test. It was observed that the enriched cheese bread is source of copper, zinc and sodium and presents high content of calcium, phosphorus and magnesium, considering the recommendations for the children's audience. The concentrations of total phenolics, flavonoids and condensed tannins increased significantly with the introduction of cowpea. It was also observed an significant increase of spermidine, cadaverine and agmatine. The antioxidant activity was statistically higher in enriched cheese bread. It is concluded, therefore, that cheese bread with cowpea contributes to the supply of minerals and bioactive compounds.
\end{abstract}

Keywords: Vigna unguiculata; bakery product; micronutrients; phenolic compounds; bioactive amines.

Practical Application: The study reports a technological innovation in the production process of a mixture of cheese bread enriched with the whole flour of biofortified cowpea. Cheese bread was chosen due to the contribution of the bakery products on a family budget. Cowpea was from a biofortified cultivation with high levels of iron, zinc, phenolics, and polyamines. The product is designed to meet the interests of consumers for foods with a better nutritional value and functional.

\section{Introduction}

Cheese bread is a traditional product of the state of Minas Gerais, Brazil, the production of which has increased considerably in recent years, in association with the growth of the market, including the export of the product. However, despite its increasing consumption, there is no standardization in terms of the manufacturing, identity and quality. Innovations that are allowed by manufacturers, such as the addition of raw materials that will enrich the product (Anjos et al., 2014; Machado \& Pereira, 2010).

The fortification presents several advantages, including the great adherence of the population, the low risk of toxicity, as the margin of harmlessness is very wide, and the non-modification of eating habits (Taddei et al., 2011), especially when they include legumes, such as the cowpea, as a vehicle of fortification.

The cowpea (Vigna unguiculata (L.) Walp) provides a significant amount of protein, 23 to $25 \%$, and carbohydrates,
$56.8 \%$, and has a large quantity of food fibers (3.9\%) and low fat $(1.3 \%)$. This raw material is characterized as a source of minerals and vitamins. There is also the presence of bioactive compounds, such as phenols and polyamines (Cavalcante et al., 2017a).

Phenolic compounds are chemical structures with hydroxyls and aromatic rings, which confer antioxidant power. In simple forms or polymers, free or complexed to sugars and proteins, these compounds originate from the secondary metabolism of plants and are essential for their growth and reproduction; in addition, they are formed under conditions of stress, such as infections, injuries, and ultraviolet radiation (UV), among others (Angelo \& Jorge, 2007). According to Hobbs et al. (2014), Lima (2005), and Martinez-Valverde et al. (2000), the growing interest in phenolic compounds stems from their association with a reduced risk of diseases, such as atherosclerosis and cancer; the bioactivity is related to the fact that phenolic compounds help control autoxidation. 
The contribution of cowpea in the content of phenolic compounds to the population is constantly reported in the literature. In researches by Barros et al. (2017), Cavalcante et al. (2017b) a variation of 89.43 to $295.23 \mathrm{mgGAE}$ (Equivalent Gallic Acid) $/ 100 \mathrm{~g}$ was observed in grains of 9 cultivars of cowpea. In the grains of the cultivar BRS Aracê, used in the present study, the content of $205.1 \mathrm{mgGAE} / 100 \mathrm{~g}$ was verified. Moreira-Araújo et al. (2017) identified among the phenolic compounds contained in cowpea, the catechin, epicatechin, gallic acid, ferulic acid and chlorogenic acid.

Bioactive amines are formed from the usual metabolic processes of animal cells, plants, and microorganisms. In addition to the antioxidant activity, polyamines (spermine and spermidine) are important in the maturation and recovery of the intestinal mucosa, the mediation of hormones and growth factors, and the synthesis of deoxyribonucleic acid (DNA), ribonucleic acid (RNA), and proteins. Biogenic amines, in turn, are neuro and vasoactive, due to their effects on vascular and neural systems. Due to its possible toxicological effects, biogenic amines in excessive quantities are a quality indicator in the food manufacturing process (Cunha et al., 2012; Glória, 2005). Barros et al. (2017) obtained values of 69.15 to $106.98 \mathrm{mg} / \mathrm{kg}$ of spermidine and 13.53 to $43.43 \mathrm{mg} / \mathrm{kg}$ of spermine in grains of four cultivars of cowpea.

Bakery products present as staple foods in alimentation and provide an ideal matrix for fortification due to consumer acceptance and convenience, enriching these products with legumes can be an effective strategy to increase / stimulate the consumption of vegetables found reduced. Thus, it was aimed to determine the mineral content, bioactive compounds and antioxidant activity of cheese bread enriched with biofortified cowpea.

\section{Materials and methods}

\subsection{Raw materials}

Cowpea (Vigna unguiculata (L.) Walp) grains of biofortified BRS Aracê cultivar were cultivated in 2017 from the experimental field of Embrapa Mid-North of Teresina-PI, which is 72 meters high at $5^{\circ} 5^{\prime} \mathrm{S} 42^{\circ} 48^{\prime} \mathrm{W}$. The grains were kept in the laboratory in low density polyethylene bags with a $0.08 \mathrm{~mm}$ thick film at a temperature of $8{ }^{\circ} \mathrm{C}$ until the time of analysis.

The other raw materials, such as sweet starch, whole milk, soybean oil, parmesan cheese, eggs, and salt, used in the formulation were obtained from local markets.

\subsection{Obtaining cowpea flour (FFC)}

According to the method of Frota et al. (2010), the cowpea grains were milled in a semi-industrial mill to obtain the whole cowpea flour $(0.5 \mathrm{mesh})$. The flour was used immediately after manufacture.

\subsection{Preparation of the cheese bread}

According to methodology adapted from Cavalcante et al. (2016) for the preparation of cheese bread, the dry ingredients (sweet starch, FFC, parmesan cheese, and salt) were homogenized and then the remaining raw materials (milk, egg, and oil) were added to the mixture. The mass was homogenized and then shaped manually, so that the loaves could acquire a round shape. The breads, arranged in greased baking tin, were roasted $\left(260^{\circ} \mathrm{C}\right.$ for $25 \mathrm{~min})$ in a pre-heated electric oven $\left(260^{\circ} \mathrm{C}\right.$ for $\left.10 \mathrm{~min}\right)$. The detailed formulations are provided in Table 1.

\subsection{Minerals}

After washing with Extran detergent (Merck), all of the glassware used remained immersed in a $25 \%(\mathrm{v} / \mathrm{v})$ nitric acid solution $\left(\mathrm{HNO}_{3}\right)$ for $24 \mathrm{~h}$. Subsequently, the glassware was rinsed with distilled and demineralized water (resistivity of $18.2 \mathrm{M}^{\prime} \Omega \mathrm{cm}^{-1}$ ).

For the preparation of the sample, dry digestion was used (Horwitz \& Latimer, 2000). The minerals were determined using the plasma emission spectrometry technique with inductive coupling (ICP OES) (Varian - Vista MPX - Mulgrave Victoria - Austrália) with axial vision, equipped with a $40 \mathrm{MHz}$ radio frequency $(\mathrm{RF})$ source, a solid state simultaneous multielement detector of the type CCD (Charge Coupled Device), a peristaltic pump, nebulizer chamber and a seaspray nebulizer. The system was fully controlled by ICP Expert software using as plasma gas the liquid argon with purity of 99.996\% (Air Liquid, SP, Brasil).

The operating conditions of the ICP OES equipment were: RF power $(1000 \mathrm{~W})$, nebulization gas flow rate $(0.9 \mathrm{~L} / \mathrm{min})$, main argon flow rate $(15 \mathrm{~L} / \mathrm{min})$, auxiliary argon flow rate $(1.5 \mathrm{~L} / \mathrm{min})$, integration and read time (10 and 5 seconds), number of replicates (3), torch configuration (axial).

\subsection{Total phenols, total flavonoids and condensed tannins}

To obtain the extracts, the procedure was adapted from Rufino et al. (2007). A $50 \mathrm{~mL}$ Falcon tube was used to weigh $3 \mathrm{~g}$ of the defatted sample, with the addition of $10 \mathrm{~mL}$ of $50 \%$ methanol. The sample was homogenised and extracted for 30 minutes with ultrasound. The sample was then centrifuged at $4000 \mathrm{rpm}$ for 15 minutes, and the supernatant transferred to a $25 \mathrm{~mL}$ volumetric flask.

To the residue of the first extraction $10 \mathrm{~mL}$ of $70 \%$ acetone was added, followed by homogenisation and extraction for 30 minutes with ultrasound. This was centrifuged at $4000 \mathrm{rpm}$ for 15 minutes, and the supernatant transferred to the same flask. The volume was topped up using Milli-Q water.

Table 1. Percentages of raw materials used in standard cheese bread formulation and in enriched formulation (F cowpea flour).

\begin{tabular}{lcc}
\hline \multicolumn{1}{c}{ Raw materials } & $\begin{array}{c}\text { Standard cheese bread } \\
(\%)\end{array}$ & $\begin{array}{c}\mathrm{F} \\
(\%)\end{array}$ \\
\hline Sweet starch & 100 & 80 \\
Cowpea flour (FFC) & - & 20 \\
Whole milk & 50 & 50 \\
Soybean oil & 20 & 20 \\
Egg & 20 & 20 \\
Parmesan cheese & 25 & 25 \\
Salt & 1 & 1 \\
\hline
\end{tabular}


The extract produced with methanol 50\%:acetone 70\%:water $(2: 2: 1)$ resulted in better extraction yields.

The content of the bioactive compounds was determined by spectrophotometric methods (BEL 1102 - Monza - Milão Itália). Total phenolics (Rossi \& Singleton, 1965), total flavonoids (Kim et al., 2003), modified by Blasa et al. (2006), and condensed tannins (Price et al., 1978).

\subsection{Bioactive amines}

Ten bioactive amines were researched, and the methodology used for the separation, detection, and quantification of amines was High Performance Liquid Chromatography (HPLC), by the pairing of ions in reverse phase column (LC - 10AD - SIL 10AD VP - Shimadzu - Kioto - Japão) (Adão \& Glória, 2005).

\subsection{Antioxidant activity}

The antioxidant activity was determined by spectrophotometric method described by Brand-Williams et al. (1995), 2,2-Diphenyl-1Pikryl-hydrazil (DPPH), and Re et al. (1999), 2,2'Azino-bis (3-ethylbenzothiazoline-6sulfonic acid) (ABTS).

\subsection{Statistical analysis}

Statistical analysis was carried out using the Statistical Package for the Social Sciences (SPSS) program, version 21.0 (International Business Machines, 2016).

Three repetitions of each formulation were performed for the chemical analysis. These were performed in triplicate and for comparison of the averages between two variables, the Student's t test was applied, and for multiple comparisons, the Tukey test was used at the level of 5\%, with a confidence interval of $95 \%$ for the tests (Andrade, 2013).

\section{Results and discussion}

According to resolution $\mathrm{N}^{\circ} .54$ from November 12, 2012, Brazilian Health Surveillance Agency (Brasil, 2012), foods that provide at least $15 \%$ and $30 \%$ of the dietary reference intake (DRI) values can receive the claims of "source" and "high content", respectively. On the exposed, the cheese bread with FFC presents itself as a source of copper, zinc, and sodium, with a high content of calcium, phosphorus, and magnesium (Table 2).

The DRI used was from children 4 to 6 years of age because of this public still being frequently affected by nutritional deficiencies, especially in developing countries like Brazil. Landim et al. (2016) evaluated the impact of ingestion of enriched cookies with biofortified cowpea (BRS Xiquexique) (pack of $30 \mathrm{~g} / 3$ times a week for 60 days) in this same public (preschool) susceptible to iron deficiency anemia. The results showed that anemia, before the intervention, the prevalence was $12.2 \%$ and after the intervention $1.4 \%$. Therefore, the efficacy of the enriched cookie with cowpea in the control of iron deficiency anemia in children was verified, besides the high acceptance of the product $(94.3 \%)$.

The mineral supply of the formulated product may be the result of the use of a biofortified raw material, with high content of iron and zinc in the grains. Simplício (2013) developed bread enriched with $25 \%$ of FFC (BRS Aracê) and determined higher levels of the minerals analyzed, with the exception of calcium (59 mg/100g). However, this result may be due to the mix of the flour used for bread making (especially wheat flour, whole-wheat flour, and FFC).

Ugwuona \& Suwaba (2013) verified an increase in the levels of calcium, iron, phosphorus, and zinc in breads enriched with $20 \%$ of defatted Jack bean flour or $20 \%$ of Jack bean protein concentrate. The levels of calcium (33 mg/100 g) and phosphorus $(13 \mathrm{mg} / 100 \mathrm{~g})$ were lower than those obtained in the present study. This difference may be the result of different formulations of the products compared.

Rybicka \& Gliszczynska-Swiglo (2017) reported that bakery products enriched with less popular raw materials, such as amaranth, chickpeas, acorns, buckwheat, oats, millet, and quinoa, are the best source of minerals, compared to the same products manufactured from popular raw materials, like rice, corn, potatoes, and wheat. Thus, incorporating products enriched in the diet improves the micronutrient intake by the population, an indispensable resource in countries with nutritional deficiencies. Considering the IDR for the adult population, enriched cheese bread is a source of calcium, phosphorus, sodium and zinc.

The addition of cowpea in the formulation of cheese bread promoted an increase $(\mathrm{p}<0.05)$ in the concentrations of the total phenolics, total flavonoids, and condensed tannins, as shown in Table 3. According to Verardo et al. (2018), formulations of multigrain breads exhibited increased amount of polyphenols and greater bioaccessibility of polyphenols and antioxidant activity than those exhibited by the standard bread.

The tegument of cowpea is the main source of the phenolic compounds, and colorful teguments have the highest concentrations. Cowpea grains of biofortified BRS Aracê cultivar (with colorful teguments) showed concentrations of total phenolics (205.1 mgGAE)/100 g) greater than those by grains of the cultivars of BRS Xiquexique (199 mgGAE/100 g), BRS Tumucumaque (177 mgGAE/100 g), BRS Millennium (133 mgGAE/100 g), BRS Itaim (132.3 mgGAE/100 g), BRS Cauamé (98.1 mgGAE/100 g), and BRS Guariba (89.4 mgGAE/100 g);

Table 2. Mineral content in cheese bread enriched with cowpea (F) and the percentage of coverage of the DRI.

\begin{tabular}{lcc}
\hline \multicolumn{1}{c}{ Minerals } & $\begin{array}{c}\text { Cheese bread with } \\
\text { cowpea (F) (mg/100g) } \\
\text { (average } \pm \text { SD) }\end{array}$ & \% DRI \\
\hline Calcium & $211 \pm 7$ & 35.2 \\
Copper & $0.07 \pm 0.0$ & 15 \\
Iron & $0.8 \pm 0.0$ & 13 \\
Phosphorus & $187 \pm 5$ & 37.4 \\
Magnesium & $25.6 \pm 0.2$ & 35 \\
Manganese & $0.2 \pm 0.0$ & 11.5 \\
Potassium & $204 \pm 10$ & 5.4 \\
Sodium & $347 \pm 14$ & 29.0 \\
Zinc & $1.3 \pm 0.0$ & 26.5 \\
\hline SD - Standard Deviation; Was considered the DRI for children from 4 to 6 years old \\
(Brasil, 2005).
\end{tabular}


both of grains with white tegument. Therefore, selection of the plant variety was effective in increasing the phenolic compounds in the developed product (Barros et al., 2017; Cavalcante et al., 2017b; Mesquita et al., 2007).

According to Moreira-Araújo et al. (2018) among the phenolic compounds identified in cowpea, stood out the catechin (2.07 to $6.48 \mathrm{mg} / 100 \mathrm{~g}$ ), epicatechin ( 0.48 to $8.67 \mathrm{mg} / 100 \mathrm{~g}$ ), gallic acid (45.4 to $93.4 \mathrm{mg} / 100 \mathrm{~g}$ ), ferulic acid (11.1 to $32.07 \mathrm{mg} / 100 \mathrm{~g}$ ) and chlorogenic acid (0.59 to $3.08 \mathrm{mg} / 100 \mathrm{~g})$.

Coelho (2014) also confirmed the increase in the total phenolics content from 197.2 to $261.9 \mu \mathrm{gGAE} / \mathrm{g}$ in breads that were enriched with chia flour (Salvia hispanica L.). This result is due to the fact that foods of plant origin are the main sources of bioactive compounds in the diet.

The compounds present from the class of total flavonoids have a significant contribution to the total phenolic content. Verardo et al. (2018) enriched bread with 30\% buckwheat and reported that the addition of whole grains in products increases especially the levels of total flavonoids and phenolic acids. In this study, an increase from 72 to $139 \mathrm{mg} / \mathrm{kg}$ in the total flavonoid content and from 37 to $97 \mathrm{mg} / \mathrm{Kg}$ in the total quantity of phenolic acids was observed.

Barros et al. (2017) verified the presence of total flavonoids in grains of four cowpea cultivars, the grains of the BRS Aracê variety exhibited a medium value of $58.35 \mathrm{mg}$ equivalent to quercetin (EQ)/100g, justifying the observed increase in the levels of total flavonoids in the enriched bread.

The condensed tannins presented a reduced contribution at 3.5 and $7.0 \mathrm{mg}$ equivalent to catechin (EC)/100g in the levels of flavonoids in the standard and enriched breads, respectively (Table 3).

In relation to the bioactive amine content, Diniz (2015) reported that cheese, in addition to fish, is associated with outbreaks of histamine intoxication, with Cheddar, Gouda, Gruyere, and Swiss cheeses being the most involved due to their high maturation periods. However, the histamine concentrations in cheeses that had already been implicated in outbreaks ranged from 850 to $1870 \mathrm{mg} / \mathrm{kg}$, which was much higher than that found in the enriched cheese bread $(7.3 \mathrm{mg} / \mathrm{Kg}$ ) (Table 4). Tyramine, which is often involved in food poisoning, and tryptamine and phenylethylamine, which have adverse effects in people sensitive to detoxification, are absent in bread with FFC.

As shown in Table 4, spermidine is the bioactive amine in greater concentration in developed products. The cowpea has a high content of this amine (129.4 mg/kg), according to the Table of Contents of Bioactive Amines in Foods (TAMIN). According to Diniz (2015) the high content of spermidine in plants is due to the participation of this polyamine in the processes of morphogenesis, rooting, flowering and senescence. Cowpea is the raw material responsible for the increase of spermidine in cheese bread enriched $(p<0.05)$ and this increase is considered appropriate when considering the antioxidant and growth effects of the polyamines.

It can be verify that the parmesan cheese is the raw material that most contributes to the levels of biogenic amines in formulations. Still according to TAMIN the legumes have little or no biogenic amine.

From the reports of Galgano et al. (2012), Linares et al. (2012), Pachlová et al. (2012), Santos et al. (2003), Spizzirri et al. (2013),

Table 3. Levels of phenolic compounds in standard and enriched cheese bread.

\begin{tabular}{lcc}
\hline \multicolumn{1}{c}{ Bioactive compounds } & $\begin{array}{c}\text { Standard cheese bread } \\
\text { (average } \pm \text { SD) }\end{array}$ & $\begin{array}{c}\text { Cheese bread with cowpea (F) } \\
\text { (average } \pm \text { SD) }\end{array}$ \\
\hline Total Phenolics (mg GAE/100g) & $105.3 \pm 5.16^{\mathrm{a}}$ & $188.4 \pm 8.92^{\mathrm{b}}$ \\
Total Flavonoids (mg EQ/100g) & $51.7 \pm 1.6^{\mathrm{a}}$ & $85.9 \pm 2.77^{\mathrm{b}}$ \\
Condensed Tannins (mg EC/100g) & $3.5 \pm 0.0^{\mathrm{a}}$ & $7.0 \pm 0.28^{\mathrm{b}}$ \\
\hline
\end{tabular}

SD - Standard Deviation; GAE - Equivalent to gallic acid; EQ - Equivalent to quercetine; EC - Equivalent to catechin; The use of the same letters between the standard cheese bread and cheese bread with cowpea indicates that there is no significant difference between the means, based on the Student's t test at the level of 5\%, 95\% confidence interval.

Table 4. Bioactive amine content in the cowpea, standard cheese bread, and cheese bread enriched with cowpea.

\begin{tabular}{|c|c|c|c|}
\hline $\begin{array}{c}\text { Bioactive } \\
\text { amines }(\mathrm{mg} / \mathrm{kg})\end{array}$ & $\begin{array}{c}\text { Cowpea } \\
\text { (Aracê cultivar) (average } \pm \mathrm{SD})\end{array}$ & $\begin{array}{l}\text { Standard cheese bread } \\
\text { (average } \pm \mathrm{SD} \text { ) }\end{array}$ & $\begin{array}{c}\text { Cheese bread with cowpea (F) } \\
\text { (average } \pm \text { SD) }\end{array}$ \\
\hline Tyramine & $\mathrm{Nd}$ & $\mathrm{Nd}$ & $\mathrm{Nd}$ \\
\hline Putrescine & $1.9 \pm 1.7^{\mathrm{b}}$ & $2.5 \pm 1.2^{\mathrm{a}}$ & $3.6 \pm 3.0^{\mathrm{a}}$ \\
\hline Cadaverine & $2.9 \pm 0.9^{\text {ca }}$ & $3.8 \pm 1.2^{\mathrm{a}}$ & $7.2 \pm 2.7^{\mathrm{b}}$ \\
\hline Histamine & $2.8 \pm 4.8^{\mathrm{b}}$ & $7.9 \pm 3.9^{a}$ & $7.3 \pm 1.8^{\mathrm{a}}$ \\
\hline Serotonin & $\mathrm{Nd}$ & $\mathrm{Nd}$ & $\mathrm{Nd}$ \\
\hline Phenylethylamine & $\mathrm{Nd}$ & $0.4 \pm 0.6^{\mathrm{a}}$ & $0.1 \pm 0.2^{\mathrm{a}}$ \\
\hline Tryptamine & $\mathrm{Nd}$ & $\mathrm{Nd}$ & $\mathrm{Nd}$ \\
\hline Spermine & $\mathrm{Nd}$ & $\mathrm{Nd}$ & $\mathrm{Nd}$ \\
\hline
\end{tabular}

SD - Standard Deviation; Nd- Not Detected. Alike letters between the cowpea flour and the standard cheese bread and bread with cowpea indicate no significant difference between the means, based on the One Way ANOVA: Post Hoc Multiple Comparisons test and the Tukey test at the level of 5\%, $95 \%$ confidence interval. 
Table 5. Antioxidant activity in standard cheese bread and enriched bread with full cowpea flour.

\begin{tabular}{ccc}
\hline Antioxidant Activity & Standard cheese bread (average \pm SD) & Cheese bread with cowpea $(\mathrm{F})($ average \pm SD) \\
\hline DPPH $(\mu$ mol TEAC/100g) & $307.4 \pm 14.7^{\mathrm{a}}$ & $497.5 \pm 14.6^{\mathrm{b}}$ \\
ABTS $(\mu \mathrm{mol}$ TEAC/100g) & $464.1 \pm 8.1^{\mathrm{a}}$ & $735.1 \pm 14.0^{\mathrm{b}}$ \\
\hline
\end{tabular}

SD - Standard Deviation; DPPH - 2,2-Diphenyl-1-Pikryl-hydrazil. ABTS - 2,2'Azino-bis (3-ethylbenzothiazoline-6sulfonic acid); TEAC - Antioxidant capacity equivalent to trolox. The use of the same letters between the standard cheese bread and cheese bread with cowpea indicates that there is no significant difference between the averages by Student's $t$ test at the level of $5 \%$, $95 \%$ confidence interval.

and Ubaldo et al. (2015), cheese contains significant levels of histamine, putrescine, cadaverine, and spermidine. The main factors affecting the formation and accumulation of biogenic amines in cheese are the availability of amino acids, the presence of microorganisms with the appropriate catabolic pathway activated and environmental conditions favorable to the decarboxylation activity.

In this way, the reduced levels of biogenic amines in the formulated products can be a result of the quality of raw materials, among them, the parmesan cheese. So, it can be affirmed that factors such as quality of milk, initial culture used, concentration of $\mathrm{NaCl}$, time and temperature of storage and maturation, $\mathrm{pH}$ and post-maturation technological processes have been properly considered during the manufacture of cheese used in the formulations, since the content of biogenic amines in cheese can reach concentrations of up to $2000 \mathrm{mg} / \mathrm{kg}$ (Linares et al., 2012).

Clearly, the cheese bread enriched with FFC presents a low content of polyamines $(<35 \mathrm{mg} / \mathrm{kg})$ and biogenic amines (Diniz, 2015). The formulated cheese bread had higher content of spermidine, cadaverine and agmatine compared to standard bread $(\mathrm{p}<0.05)$. Due to the absence of agmatine in cowpea analyzed, the increase of this biogenic amine may be the result of the manufacturing process.

The introduction of the cowpea increased the concentration of the bioactive compounds in the product, and, consequently, the ability to trap free radicals. This increase is in accordance with the work of Barros et al. (2017), in which the grains in the BRS Aracê cultivar had an antioxidant activity of 614.7 and $660.1 \mu \mathrm{mol}$ antioxidant capacity equivalent to Trolox (TEAC)/100 g, determined by DPPH and ABTS methods, respectively. These values were higher than those obtained in the grains of the cultivars of BRS Millennium, BRS Tumucumaque, and BRS Xiquexique.

As shown in Table 5 the enriched cheese bread had the highest antioxidant activity $(\mathrm{p}<0.05)$ determined by both methods, DPPH and ABTS, with 497.5 and $735.1 \mu \mathrm{mol}$ TEAC/100 g, respectively.

Two methods were employed because of the different characteristics and mechanisms of action of the bioactive compounds, as well as the principles of the methods and the nature of the radicals.

It can be verify that an increase in the raw material sources bioactive compounds improves the antioxidant activity of bakery products. In a search by Lin \& Zhou (2018), it was observed that the gradual fortification of quercetin in bread formulation resulted in a significant increase in the antioxidant activity in vitro. This increase was from 2.9 to $285.8 \mathrm{mg} \mathrm{TEAC} / 100 \mathrm{~g}$ and 8.4 to $298.5 \mathrm{mg} \mathrm{TEAC} / 100 \mathrm{~g}$, using the radical ABTS and DPPH, respectively.
Although the bread with FFC had a greater antioxidant activity $(\mathrm{p}<0.05)$, the standard formulation presents a significant content, which may be due to the antioxidant properties of the Maillard reaction products formed in the crust of the bread, according to Buchner et al. (2006), Lin \& Zhou (2018), and Sivam et al. (2010). The phenolic compounds intrinsic of the food and the intermediate products of the thermal degradation of phenolic compounds, as well as the compounds from the complex polyphenol-protein/starch can contribute to the antioxidant properties of the formulated products.

\section{Conclusions}

In terms of the mineral content, the formulated product is source of copper, zinc, and sodium and has a high content of calcium, phosphorus, and magnesium.

The total phenolic content, total flavonoids, and condensed tannins increased in the enriched cheese bread.

The cheese bread enriched with FFC presented low levels of biogenic amines. The formulated product had higher content of spermidine, cadaverine and agmatine compared to standard bread.

With the increase in the concentration of the bioactive compounds, it was possible to verify the improvement of the antioxidant activity of the cheese bread with cowpea.

It was therefore concluded that the cowpea, a regional and market-expanding raw material, presents itself as a viable option for the enrichment of gluten-free bakery foods, such as cheese bread. In addition to the supply of important nutrients, the formulated product presents itself as a vehicle for bioactive compounds.

\section{References}

Adão, R. C., \& Glória, M. B. A. (2005). Bioactive amines and carbohydrate changes during ripening of 'Prata' banana (Musa acuminate $\mathrm{x}$ M. balbisiana). Food Chemistry, 90(4), 705-711. http://dx.doi. org/10.1016/j.foodchem.2004.05.020.

Andrade, D. F. (2013). Statistics for agrarian and biological sciences: experimental concepts (3th ed.). Florianópolis: Ed. da UFSC.

Angelo, P. M., \& Jorge, N. (2007). Compostos fenólicos em alimentos - uma breve revisão. Revista Instituto Adolfo Lutz, 66(1), 232-240.

Anjos, L. D., Pereira, J., Couto, E. M., \& Cirillo, M. A. (2014). Modified starches or stabilizers in preparation of cheese bread. Ciência Rural, 44(9), 1686-1691. http://dx.doi.org/10.1590/0103-8478cr20131133.

Barros, N. V. A., Rocha, M. M., Glória, M. B. A., Araújo, M. A. M., \& Moreira-Araújo, R. S. R. (2017). Effect of cooking on the bioactive compounds and antioxidant activity in grains cowpea cultivars. Ciência Agronômica, 28(5), 824-831. http://dx.doi.org/10.5935/18066690.20170097. 
Blasa, M., Candiracci, M., Accorsi, A., Piacentini, M. P., Albertini, M. C., \& Piatti, E. (2006). Raw Millefiori honey is packed full of antioxidants. Food Chemistry, 97(2), 217-222. http://dx.doi. org/10.1016/j.foodchem.2005.03.039.

Brand-Williams, W., Cuvelier, M. E., \& Berset, C. (1995). Use of a free radical method to evaluate antioxidant activity. FLWT - Food Science and Technology, 28(1), 25-30. http://dx.doi.org/10.1016/ S0023-6438(95)80008-5.

Brasil. Ministério da Saúde. (2005). Dispõe sobre o regulamento técnico sobre a ingestão diária recomendada (IDR) de proteína, vitaminas e minerais (Resolução n 269, de 22 de setembro de 2005). Diário Oficial [da] República Federativa do Brasil.

Brasil. Ministério da Saúde. (2012). Dispõe sobre o Regulamento Técnico sobre Informação Nutricional Complementar (Resolução $\mathrm{n}^{\circ}$. 54, de 12 de novembro de 2012). Diário Oficial [da] República Federativa do Brasil.

Buchner, N., Krumbein, A., Rohn, S., \& Kroh, L. W. (2006). Effect of thermal processing on the flavonols rutin and quercetin. Rapid Communications in Mass Spectrometry, 20(21), 3229-3235. http:// dx.doi.org/10.1002/rcm.2720. PMid:17016866.

Cavalcante, R. B. M. C., Morgano, M. A., Silva, K. J. D., Rocha, M. M., Araújo, M. A. M., \& Moreira-Araújo, R. S. R. (2016). Cheese bread enriched with biofortified cowpea flour. Ciência e Agrotecnologia, 40(1), 97-103. http://dx.doi.org/10.1590/S1413-70542016000100009.

Cavalcante, R. B. M., Araújo, M. A. M., Rocha, M. M., \& MoreiraAraujo, R. S. R. (2017a). Effect of thermal processing on chemical compositions, bioactive compounds, and antioxidant activities of cowpea cultivars. Revista Caatinga, 30(4), 1050-1058. http://dx.doi. org/10.1590/1983-21252017v30n426rc.

Cavalcante, R. B. M., Araújo, M. A. M., Rocha, M. M., Silva, K. J. D., \& Moreira-Araújo, R. S. R. (2017b). Effect of thermal processing on total polyphenol content in the grain of cowpea cultivars. Ciência Agronômica, 48(5), 806-810. http://dx.doi.org/10.5935/18066690.20170094 .

Coelho, M. S. (2014). Pão enriquecido com chia (Salvia hispanica L.): desenvolvimento de um produto funcional (Dissertação de mestrado). Universidade Federal do Rio Grande, Rio Grande.

Cunha, F. L., Conte, C. A. Jr., Lázaro, C. A., Santos, L. R., Mársico, E. T., \& Mano, S. B. (2012). Determinação de aminas biogênicas em diferentes tipos de queijos por cromatografia líquida de alta eficiência. Revista do Instituto Adolfo Lutz, 71(1), 69-75.

Diniz, F. B. (2015). Elaboração de tabela de aminas bioativas em alimentos e estimativa da ingestão no Brasil (Dissertação de mestrado). Universidade Federal de Minas Gerais, Belo Horizonte.

Frota, K. M. G., Morgano, M. A., Silva, M. G., Araújo, M. A. M., \& Moreira-Araújo, R. S. R. (2010). Utilização da farinha de feijãocaupi (Vigna unguiculata (L.) Walp) na elaboração de produtos de panificação. Food Science and Technology (Campinas), 30(1), 44-50.

Galgano, F., Caruso, M., Condelli, N., \& Favati, F. (2012). Focused: agmatine in fermented foods. Frontiers in Microbiology, 3(1), 1-7. PMid:22701114.

Glória, M. B. A. (2005). Amines. In H. Hui \& L. L. Nollet (Eds.), Handbook of food science (cap. 13, p. 38). New York: Marcel Dekker.

Hobbs, D. A., Ashouri, A., George, T. W., Lovegrove, J. A., \& Methven, L. (2014). The consumer acceptance of novel vegetable-enriched bread products as a potential vehicle to increase vegetable consumption. Food Research International, 58(1), 15-22. http://dx.doi.org/10.1016/j. foodres.2014.01.038.
Horwitz, W., \& Latimer, G. Jr. (2000). Official Methods of Analysis of the Association of Official Analytical Chemists (17th ed.). Maryland: AOAC.

International Business Machines - IBM. (2016). Statistical Package for the Social Sciences - SPSS, versão 21.0. New York: IBM.

Kim, D., Jeong, S. W., \& Lee, C. Y. (2003). Antioxidant capacity of phenolic phytochemicals from various cultivars of plums. Food Chemistry, 81(1), 321-326. http://dx.doi.org/10.1016/S0308-8146(02)00423-5.

Landim, L. A. S. R., Pessoa, M. L. S. B., Brandão, A. C. A. S., Morgano, M. A., Araújo, M. A. M., Rocha, M. M., Arêas, J. A. G., \& MoreiraAraújo, R. S. R. (2016). Impact of the two different iron fortified cookies on treatment of anemia in preschool children in Brazil. Nutrición Hospitalaria, 33(5), 1142-1148. http://dx.doi.org/10.20960/ nh.579. PMid:27759983.

Lima, D. E. S. (2005). Influência do melhoramento genético convencional sobre os constituintes do feijão-caupi (Vigna unguiculata (L.) Walp) (Dissertação de mestrado). Universidade Federal de Pernambuco, Recife.

Lin, J., \& Zhou, W. (2018). Role of quercetin in the physicochemical properties, antioxidant and antiglycation activities of bread. Journal of Functional Foods, 40(1), 299-306. http://dx.doi.org/10.1016/j. jff.2017.11.018.

Linares, D. M., Del Río, B., Ladero, V., Martínez, N., Fernández, M., Martín, M. C., \& Álvarez, M. A. (2012). Factors influencing biogenic amines accumulation in dairy products. Frontiers in Microbiology, 3(180), 1-10. http://dx.doi.org/10.3389/fmicb.2012.00180. PMid:22783233.

Machado, A. V., \& Pereira, J. (2010). Effect of scalding on technological and rheological properties of cheese bread dough and cheese bread. Ciência e Agrotecnologia, 34(2), 421-427. http://dx.doi.org/10.1590/ S1413-70542010000200021.

Martinez-Valverde, L., Periago, M. J., \& Ros, G. (2000). Nutritional importance of phenolic compounds in the diet. Archivos Latinoamericanos de Nutricion, 50(1), 5-18. PMid:11048566.

Mesquita, F. R., Corrêa, A. D., Abreu, C. M. P., Lima, R. A. Z., \& Abreu, A. F. B. (2007). Linhagens de feijão (Phaseolus vulgaris L.): composição química e digestibilidade protéica. Ciência e Agrotecnologia, 31(4), 1114-1121. http://dx.doi.org/10.1590/S1413-70542007000400026.

Moreira-Araújo, R. S. R., Sampaio, G. R., Soares, R. A. M., Silva, C. P., Araújo, M. A. M., \& Arêas, J. A. G. (2018). Identification and quantification of phenolic compounds and antioxidant activity in cowpeas of BRS Xiquexique cultivar. Revista Caatinga, 31(1), 209216. http://dx.doi.org/10.1590/1983-21252018v31n124rc.

Moreira-Araújo, R. S. R., Sampaio, G. R., Soares, R. A. M., Silva, C. P., \& Arêas, J. A. G. (2017). Identification and qualification of antioxidant compounds in cowpea. Ciência Agronômica, 48(5), 799-805. http:// dx.doi.org/10.5935/1806-6690.20170093.

Pachlová, V., Bunka, F., Flasarová, R., Válková, P., \& Bunková, L. (2012). The effect of elevated temperature on ripening of dutch type cheese. Food Chemistry, 132(1), 1846-1854. http://dx.doi.org/10.1016/j. foodchem.2011.12.017.

Price, M. L., Van Scoyoc, S., \& Butler, L. G. (1978). A critical evaluation of the vanillin reaction as an assay for tannin in sorghum grain. Journal of Agricultural and Food Chemistry, 26(1), 1214-1218. http:// dx.doi.org/10.1021/jf60219a031.

Re, R., Pellegrini, N., Proteggente, A., Pannala, A., Yang, M., \& RiceEvans, C. (1999). Antioxidant activity applying an improved ABTS radical cation decolorization assay. Free Radical Biology \& Medicine, 26(9), 1231-1237. http://dx.doi.org/10.1016/S0891-5849(98)003153. PMid:10381194. 
Rossi, J. A., \& Singleton, V. L. (1965). Colorimetry of total phenolics with phosphomolybdic-phosphotungstic acid reagents. American Journal of Enology and Viticulture, 20(2), 144-158.

Rufino, M. S. M., Alves, R. E., Brito, E. S., Morais, S. M., Sampaio, C. G., Pérez-Jiménez, J., \& Saura-Calixto, F. D. (2007). Metodologia científica: determinação da atividade antioxidante total em frutas pela captura do radical livre DPPH. (Comunicado Técnico, $\mathrm{n}^{\circ} 127$ ). Brasília: Embrapa Meio-Norte.

Rybicka, I., \& Gliszczynska-Swiglo, A. (2017). Minerals in grain glutenfree products. The content of calcium, potassium, magnesium, sodium, copper, iron, manganese and zinc. Journal of Food Composition and Analysis, 59(1), 61-67. http://dx.doi.org/10.1016/j.jfca.2017.02.006.

Santos, W. C., Souza, M. R., Cerqueira, M. O. P., \& Gloria, M. B. A. (2003). Bioactive amines formation in milk by Lactococcus in the presence or not of rennet and $\mathrm{NaCl}$ at 20 and $32^{\circ} \mathrm{C}$. Food Chemistry, 81(1), 595-606. http://dx.doi.org/10.1016/S0308-8146(02)00502-2.

Simplício, A. P. M. (2013). Desenvolvimento de pão integral enriquecido com farinha de cultivares de feijão-caupi (Vigna unguiculata (L.) Walp) (Dissertação de mestrado). Universidade Federal do Piauí, Teresina.

Sivam, A. S., Sun-Waterhouse, D., Quek, S., \& Perera, C. O. (2010). Properties of bread dough with added fiber polysaccharides and phenolic antioxidants: a review. Journal of Food Science, 75(8),
R163-R174. http://dx.doi.org/10.1111/j.1750-3841.2010.01815.x. PMid:21535512.

Spizzirri, U. G., Restuccia, D., Curcio, M., Parisi, O. I., Iemma, F., \& Picci, N. (2013). Determination of biogenic amines in different cheese samples by LC with vaporative light scattering detector. Journal of Food Composition and Analysis, 29(1), 43-51. http:// dx.doi.org/10.1016/j.jfca.2012.09.005.

Taddei, J. A. A. C. T., Lang, R. M. F., Longo-Silva, G., \& Toloni, M. H. A., editors (2011). Nutrição em saúde pública. Rio de Janeiro: Rubio.

Ubaldo, J. C. S. R., Carvalho, A. F., Fonseca, L. M., \& Glória, M. B. A. (2015). Bioactive amines in Mozzarella cheese from milk with varying somatic cell counts. Food Chemistry, 178(1), 229-235. http://dx.doi. org/10.1016/j.foodchem.2015.01.084. PMid:25704706.

Ugwuona, F. U., \& Suwaba, S. (2013). Effects of defatted jack bean flour and jack bean protein concentrate on physicochemical and sensory properties of bread. Nigerian Food Journal, 31(2), 25-32. http://dx.doi.org/10.1016/S0189-7241(15)30073-4.

Verardo, V., Glicerina, V., Cocci, E., Frenich, A. G., Romani, S., \& Caboni, M. F. (2018). Determination of free and bound phenolic compounds and their antioxidant activity in buckwheat bread loaf, crust and crumb. Lebensmittel-Wissenschaft + Technologie, 87(1), 217-224. http://dx.doi.org/10.1016/j.lwt.2017.08.063. 